\title{
THE HISTORY OF THE DEVELOPMENT OF CRIMINAL LEGISLATION OF AZERBAIJAN ON ENVIRONMENTAL CRIMES (1960-2000 YEARS)
}

\author{
HUSEYNOVA Shahla - PhD candidate of the Azerbaijan National Academy of \\ Aviation \\ ГУСЕЙНОВА Шахла Асадулла кызы - диссертант Национальной Академии \\ Авиации Азербайджана
}

DOI:10.32782/EP.2020.1.13

Article 160. Violation of fishery protection rules: "Discharge of unclean and decontaminated water from industrial and municipal facilities to fishery waters, or carrying out blasting operations in violation of established rules for the protection of fish resources shall be punishable by up to one year of imprisonment or corrective labor for the same period or fined up to three hundred mantas".

Article 161. Illegal hunting: "The hunting which has been carried out without appropriate sanction either in prohibited zones or in forbidden time, or by forbidden instruments and ways, if these actions were made after administrative penalties for the same offense, shall be punishable by confiscation of all catch items and all hunting tools or without it, up to six months of corrective labor or a fine at a rate of fifty manats.

Article 163. Violation of Water Use Rules in Irrigated Farming Areas: "Unauthorized seizure of water in irrigated agricultural areas or unauthorized hydrotechnical work in the public use network, as well as any other violation of water use rules in the specified areas, if earlier administrative or public actions were applied for such actions, shall be punishable by up to one year of corrective labor or fine up to fifty manats.

Deliberate damage or damage to water facilities - irrigation canals, collectors, drains and various hydraulic facilities, if they have caused significant damage - shall be punishable by up to one year of corrective labor or a fine up to one hundred mantas".
Article 164. Illegal cutting of trees: "Illegal cutting of trees in forests or kolkhoz forests or in specially protected forest areas, when committed in a form of business or cutting of trees in a significant amount shall be punishable by up to one year of imprisonment or corrective labour for the same term with confiscation of any forest products cut or a fine up to one hundred mantas".

Article 165. Commitment of Forest Fire: "Committing a forest fire resulting in serious consequences from negligence - shall be punished by imprisonment for up to two years or corrective labor for up to one year".

By the decree of the Presidium of the Supreme Soviet of Azerbaijan SSR dated April 29, 1972, the name and contents of Article 160 of the Criminal Code of the Azerbaijani SSR dated December 8, 1960 were changed and the following new Articles were added to the said Code. Article 158-1 and 160-1 (Contamination of the sea by substances harmful to human health or marine life) by the Decree of April 8, 1975, Article 224-1 by the Decree of December 22, 1982, Article 162-2 by the Decree of July 22, 1985 and after the independence of the Republic of Azerbaijan, by the Act of February 7, 1997, Articles 160-2 and 224-2. The last two (2) articles are included in the tenth chapter of the Code "Crimes against public security and public order". Let's look through the contents of some articles mentioned.

Article 158-1.Infringement of legislation of the USSR about a coastal shelf: "Illegal 
erection of constructions or other installations on a coastal shelf of the USSR, illegal creation of safety zones around them; not provide protection of constructions on a coastal shelf of the USSR and other installations, not taking measures to protect marine resources in security zones from wastes, shall be punishable by imprisonment for one year and fine up to ten thousand manat or imprisonment for one year or fine up to ten thousand manat.

Research, investigation, development of natural resources and implementation of other activities on a continental shelf of the USSR by foreign legal or physical persons, if implementation of these works is not provided by international agreements to which the USSR is a party or in the special sanction given by the appropriate state body of the USSR - shall be punishable by imprisonment for one year and fine up to ten thousand manat with confiscation of the boat, all tools of offender, moreover all items that were illegally obtained or imprisonment for one year or fine up to ten thousand manat".

Article 160. Water reservoir and air pollution: "Pollution of the sea, rivers, lakes and other water reservoirs and water sources by uncleaned and untreated waste water from industrial, agricultural, communal and other enterprises, institutions and organizations that caused or could cause harm to human health or agricultural production, or fish stocks, as well as air pollution by industrial wasre that harmful to human health shall be punishable by correctional labor for a term of up to one year or a fine in the amount of three hundred manats.

The same actions that have caused significant harm to human health or agricultural production, or actions caused the mass death of fish- shall be punishable for a term of five year imprisonment".

Article 160-2. Damage to the domestic animal gene pool: "Massive destruction, deliberate reduction of breeding animals that cause damage to the local animal gene pool - shall be punishable by imprisonment up to three years or up to two years of corrective labor".
Article 162-2. Improvidently use of land and soil pollution. "Improvidently use of land, failure to comply with mandatory measures to improve land and protect soils from wind, water erosion and other processes that worsen the condition of soils, damage to agricultural and other lands, pollution of lands with industrial and other waste and sewage, the use of land not in accordance with those the purposes for which they are provided, if it has caused significant harm or worsened the fruitful layer of the soil, shall be punishable by imrisonment for a term of up to two years or correctional labor for a term of up to one year, or a fine in the amount of three hundred manats".

Article 224-1. Violation of veterinary rules: "Violation of veterinary rules, which entailed the spread of epizootics or other serious consequences, shall be punishable by imrisonment for a term of up to three years or correctional labor for a term of up to two years".

Article 224-2. Violation of plant quarantine rules: "Violation of rules of plant quarantine and pest control related to plant quarantine objects, as defined by law, entails serious consequences -shall be punished with corrective labour up to one year".

We would like to note that by the Law of the Republic of Azerbaijan dated October 21, 1994, No. 913, the words "Azerbaijan SSR" in the name of the Criminal Code of the Azerbaijani SSR dated December 8, 1960, were replaced by the words "Republic of Azerbaijan". During the effective period of the Code, amendments and additions have been made to some articles on the of environmental protection issues.

Separate chapter (Chapter XXVIII) is included in the new Criminal Code of the Republic of Azerbaijan, effective from September 1, 2000, and Articles 247-261 of the Code specify the nature of criminal liability and related penalties for the following environmental crimes.

1) Article 247 - Infringement of protection rules on environment by manufacture of works;

2) Article 248 - Infringement of rules on handling with ecologically dangerous substances and waste products; 


\section{Кримінальне право, кримінальний процес та криміналістика}

3) Article 249 - Infringement of veterinary rules and rules established for struggle against plant diseases and pests;

4) Articl 250 - Pollution of water (water sources);

5) Article 251- Pollution of an atmosphere;

6) Article 252 - Pollution of marine environment;

7) Article 253 - Infringement of the legislation of the Republic of Azerbaijan about a coastal shelf;

8) Article 254 - Damage of ground;

9) Article 255 - Violation of the rules for the protection and use of earth's crust;

10) Article 256 - Illegal catching fish and other water bioresources;

11) Article 257 - Violation of the rules for protection of fish and other water bioresources;

12) Article 258 - Illegal hunting;

13) Article 259 - Illegal cutting of trees;

14) Article 260 - Desturction or damage forests or other greenery;

15) Article 261- Violation of protection regime of specially protected natural areas and natural objects.

As it can be seen, article 15 of the new Criminal Code of the Republic of Azerbaijan deals with environmental crimes.

It is important to inform that Articles 247, 248, 255, 257 and 261 of the Criminal Code are new to the criminal legislation of our republic. Thus, Criminal Code of Azerbaijan SSR dated December 8, 1960 did not envisage a crime the followings: Infringement of protection rules on environment by manufacture of works;infringement of rules on handling with ecologically dangerous substances and waste products; violation of the rules for the protection and use of earth's crust; violation of the rules for protection of fish and other water bioresources.

Articles 249, 250, 251, 252, 253, 254, 256, 259 and 260 of the Criminal Code of the Republic of Azerbaijan cannot be considered new in the criminal legislation of the Republic. Because the criminal liability for the acts mentioned in these articles is also reflected in the Criminal Code of the Azerbaijani SSR dated December 8, 1960.
With regard to Article 258 of the Criminal Code of the Republic of Azerbaijan, we would like to note that this article with a number of additions made by the legislation can be considered a new form of Article 161 entitled "Illegal Hunting" of the Criminal Code of the Azerbaijani SSR dated December 8, 1960.

Unlike the previous Criminal Code, Article 258 of the effective Criminal Code did not envisage administrative prejudice as the main element of criminal liability for illegal hunting, this article includes the provision of "considerable damage" as a basis for criminal liability and envisages completely new guidelines. Thus Article 258 of the new Criminal Code envisages: "The hunting which has been carried out without appropriate sanction either in prohibited zones or in forbidden time, or by forbidden instruments and ways, causing damage in the significant amount - shall be punishable by the penalty at a rate from two thousand to three thousand manats, or public works for the term from two hundred forty to three hundred twenty hours, or corrective works for the term up to one year, or restraint of liberty for the term up to one year".

The same act committed: by causing damage in the large amount; with use of explosives or different ways of mass destruction of birds and animals; concerning birds and animals, hunting on which is forbidden completely; on territory of reserve or in zone of ecological disaster or in a zone of an extreme ecological situation - shall be punishable by the penalty at a rate from three thousand to six thousand manats, or corrective works for the term up to one year, or restraint of liberty for the term up to two years, or imprisonment for the term up to two years.

The act provided by articles 258.1 and 258.2 of the present Code, committed by official with use of the service position; on preliminary arrangement by group of persons or organized group - shall be punishable by the penalty at a rate from six thousand to nine thousand manats, or restraint of liberty for the term from two up to five years, or with imprisonment for the term from two up to five years with deprivation of the right to hold the certain posts or to engage in the cer- 
tain activity for the term up to three years or without it.

Note: "The significant amount" in article 258.1 of the present Code is understood as the sum at a rate of from four hundred up to one thousand manats, and as "the large amount" in article 258.2.1 - over one thousand manats".

Thus, the results of the research allow us to reach the following conclusions.

Although the term "environmental crime" is not used in the Criminal Code of Azerbaijan SSR dated December 8, 1960, Article 12 of that Code deals with environmental issues. Articles 158-1, 159, 160, 160-1, 160-2, 161, 162-2, 163, 164 and 165-are highlighted in the Chapter six titled "Crime in sphere of economic activities" Articles 224-1 and 224-2-highlighted in the Chapter X "Crimes against public safety and public order".

It is noteworthy that in the new Criminal Code of the Republic of Azerbaijan effective September 1, 2000, for the first time the term "environmental crime" is used, and a separate chapter (Chapter XXVIII) is intorduced to these crimes (Articles 247-261). Although Articles 247, 248, 255, 257 and 261 of this Code are new to the criminal law of our country, Articles 249, 250, 251, 252, 253, 254, 256, 259 and 260 cannot be considered new. Because the criminal liability for the acts envisaged in the last articles was also reflected in the Criminal Code of the Azerbaijani SSR dated December 8, 1960. Article 258 of the Criminal Code, which is in force, was created in accordance with Article 161 of the Criminal Code of Azerbaijan SSR dated December 8,1960 .

\section{Bibliographic references}

1. Bulletin of the Supreme Soviet of the Soviet Socialist Republic of Azerbaijan, 1972, No. 7-8, Article 21.

2. Bulletin of the Supreme Soviet of the Soviet Socialist Republic of Azerbaijan, 1985, No. 13-14, Article 301.

3. Bulletin of the Supreme Soviet of the Soviet Socialist Republic of Azerbaijan, 1982, No 24, Article 292.

4. Bulletin of the Supreme Soviet, 1995, № 10 , Article 192.
5. Commentary of the Criminal Code of the Republic of Azerbaijan / edited by Doctor of Law,F.Y.Samandarov, Baku, Digesta,2012, $1104 \mathrm{p}$.

6. Criminal Code of the Azerbaijan SSR dated December 8, 1960. Proceedings of the Supreme Soviet of the Azerbaijan Soviet Socialist Republic, 1960, No. 29, article 143.

7. Law Collection of the Republic of Azerbaijan, 1997, No. 4, Article 151.

8. Law collection of the Republic of Azerbaijan, 1997, No. 4, Article 151.

9. Proceedings of the Supreme Soviet of the Soviet Socialist Republic of Azerbaijan, 1975, No. 7, article 48.

Гусейнова Шахла Асадулла квизи - диссертант Начиональной Академии Авиачии Азербайджана ИСТОРИЯ РАЗВИТИЯ УГОАОВНОГО ЗАКОНОДАТЕАЬСТВА АЗЕРБАЙДЖАНА ОБ ЭКОАОГИЧЕСКИХ ПРЕСТУПАЕНИЯХ (1960-2000 ГОДЫ)

В статье указывается, что Уголовный кодекс Азербайджанской ССР, который вступил в силу 1 марта 1961 года, имел задачи охраны общественного строя Азербайджанской Республики, его политической и экономической систем, собственности, личности, прав и свобод граждан, а также всего правопорядка от преступных посягательств. Для осуществления этой задачи Уголовный кодекс Азербайджанской ССР определял, какие общественно опасные деяния являются преступными, и устанавливал наказания, подлежащие применению к лицам, совершившим преступления.

В 3-й статье указанного Кодекса отмечалось, что уголовной ответственности и наказанию подлежит только лицо, виновное в совершении преступления, то есть умышленно или по неосторожности совершившее предусмотренное уголовным законом общественно опасное деяние. Никто не может быть признан виновным в совершении преступления, а также подвергнут уголовному наказанию иначе как 


\section{Кримінальне право, кримінальний процес та криміналістика}

в соответствии с законом и по приговору суда, вступившему в законную силу.

Шесть статей указанного Кодекса - статьи 159, 160, 161, 163, 164 и 165 была посвящена вопросам о защите окружающей среды. Эти статьи нашли свое отражение в шестой главе под названием «Хозяйственные преступления».

В статье 159, которая называлась «Незаконное занятие рыбным или другими водными добывающими промыслами» говорилось: «Производство рыбного, звериного или иного водного добывающего промысла в рыбохозяйственных водоемах без надлежащего разрешения или в запретное время, или в недозволенных местах, или запрещенными способами и орудиями лова, - наказывается лишением свободы на срок до одного года или исправительными работами на тот же срок, или штрафом в размере от трехсот пятидесяти до четырехсот минимальных заработных плат с конфискацией добытого, орудий лова и плавучих средств с их принадлежностями.

Те же действия, если они совершены повторно или сопряжены с уловом или убоем ценных пород рыб или водных животных, либо с причинением крупного ущерба, - наказываются лишением свободы на срок до четырех лет с конфискацией имущества или без таковой.

Ключевые слова: Кодекс, право, законодательство, здоровье, статья.

\section{SUMMARY}

If we take a view of history of criminal legislation of Azerbaijan related to environmental crimes we can see that Article 1 of the Criminal Code of Azerbaijan SSR, consisted of 264 articles, which was ratified by the law of Azerbaijan SSR dated December 8, 1960 came into force on March 1, 1961, stated the following: "The function of the Criminal Code of the Azerbaijan SSR is to protect Soviet social and state structures, socialist property, personal and citizen rights and all socialist rules from criminal conspiracy.

To accomplish this task, the Criminal Code of the Azerbaijan SSR defines what socially dangerous acts constitute criminal act and imposes penalties on the perpetrators ".

Article 3 of the same Code stated that "only a person guilty of committing a crime, that is, a person who has committed a deliberate or negligent act of public danger, as provided by the criminal law, shall be prosecuted and punished.

Criminal punishment can only be imposed by a court order".

In the initial edition of the mentioned Code, six (6) articles - Articles 159, 160, 161, 163, 164 and 165 were devoted to environmental issues. These items are set out in Chapter Six, entitled "Crime in sphere of economic activities", as follows.

Article 159. Illegal extraction of a fish and other aquatic bioresources: "Illegal extraction of fish and other aquatic bioresources in forbidden time and place with banned hunting tools and methods and if these actions were made after administrative penalties for the same offense or for the first time, but if fishing tools, explosives or poisonous substances were used shall be punishable by of corrective labor with confiscation of all catch items and all hunting tools up to one year or a fine at a rate of five hundred manats".

Key words: Code, law, legislation, health, article. 